\title{
Impacts of Gated Communities on Residential Property Values: A Comparison of ONIPETESI Estate and Its Neighbourhoods in IKEJA, Lagos State, Nigeria
}

\author{
AJIBOLA, M. O. (Corresponding author) \\ Department of Estate Management, School of Environmental Sciences \\ College of Science and Technology, Covenant University, Ota, Nigeria \\ GSM: 234 (0) 8023029220 E-mail: solaajibola2000@yahoo.com \\ OLOKE, O. C. \\ Department of Estate Management, School of Environmental Sciences \\ College of Science and Technology, Covenant University, Ota, Nigeria \\ GSM: 234 (0) 7032244140 E-mail: c_yinkaoloke@yahoo.com
}

OGUNGBEMI, A. O.

Department of Estate Management, Lagos State Polytechnic

Ikorodu, Lagos State, Nigeria

GSM: 234 (0) 8035775341 E-mail: yogungbemi@yahoo.com

Received: December 2, 2010

Accepted: December 20, 2010

doi:10.5539/jsd.v4n2p72

\begin{abstract}
There has been a considerable growth of interest in recent years surrounding the emergence of gated communities. This study examined the impact of gated communities on residential property values by comparing Onipetesi Estate and Idi-Mangoro neighbourhood. While questionnaire was administered on the 230 residents of Onipetesi Estate, 40 copies were administered on the Estate Surveying and Valuation firms managing properties within Onipetesi Estate and Idi-Mangoro neighbourhood. A total of 134 (58.26\%) and 25 (62.5\%) copies of the questionnaires were retrieved from the residents and Managing Agents respectively. In analysing the data collected for this study, descriptive statistics was adopted. The study revealed that residential properties within Onipetesi Estate are more expensive than that of Idi-Mangoro. The study further revealed that the quest for security of life and properties is a major factor attracting people to the estate. In terms of economic sustainability, gated communities provide good basis for improving the standard and quality of valuation of residential properties, however both environmental and social sustainability should be given equal recognition, especially with the various criticisms leveled against gated communities in terms of their sustainability contribution to urban growth.
\end{abstract}

Keywords: Community, Estate, Gate, Impacts, Neighbourhood, Sustainability

\section{Introduction}

"A gated community is a housing development on private roads closed to general traffic by a gate across the primary access. The developments may be surrounded by fences, walls, or other natural barriers that further limit public access". Grant and Mittelsteadt (2004; 913)

There has been a considerable growth of interest in recent years surrounding the emergence of 'gated communities', 'fortified enclaves' and other forms of privatized public space (Atkinson and Flint, 2004). This interest has been found in the work of sociologists and anthropologists who have focused on the residents of these developments as well as urban and regional theorists who have linked the emergence of gated residential developments (GRDs) to wider processes of economic and urban restructuring that have been associated with globalization (Low, 2003).

Gated communities are residential areas with restricted access designed to privatize normally public spaces. These new residential areas occur in both new suburban developments and older inner city areas for the purposes of 
security and segregation. The developers of gated communities brilliantly market their projects as safer, friendlier, and more economically stable traditional urban or even suburban neighbourhoods. Gated communities came about as a result of larger cities not being able to use gates and fences due to the high population density. Gated communities formed in early years of the nineteenth century were mostly for old and retired people, important members of the community and handicapped persons. Some gated communities, usually called guard-gated communities, are staffed by private security guards and are often high-value properties, or set up as retirement villages. Some gated communities are secure enough to resemble fortresses.

The gating of a residential area is not a new phenomenon. During the Middle Ages and the Renaissance, kings and other royalty provided gated enclaves for their families and loyal followers during times of siege and pestilence. "Fortified with towers, moats, and drawbridges, they stood as formidable reminders of class distinctions" (Dillon, 1994). Since the real estate boom in the late 1980 's, this rapidly growing phenomenon of gating off communities has become more prevalent in today's society. In its modern form, a gated community is a form of residential community or housing estate containing strictly-controlled entrances for pedestrians, bicycles, and automobiles, and often characterized by a closed perimeter walls and fences. Gated communities usually consist of small residential streets and include various shared amenities. For smaller communities this may be only a park or other common areas whereas for larger communities, it may be possible for residents to stay within the community for most day-to-day activities.

Currently, there is no national policy on enclosed neighbourhoods or road closures for security purposes in Nigeria. No legislation either overtly or covertly to provide for "gated communities", "road closures" or "neighbourhood enclosures", or "security estates". Over the years, there have been several criminal acts within the length and breadth of the country as a result of inefficient security. This has culminated into the loss of lives of able bodied men and women that were murdered in their unprotected residences even within the designated high-brow residential areas of the nation. A typical example of such scenarios was the murder of a serving Minister of Justice and Attorney General of the Federation right in his bedroom in 2001. The estate where he resided in Ibadan was easily accessible from the neighbourhood and there was no security procedure in place to restrict movement in and out of the estate. The estate did not have a fence, security gate and security personnel. Vis-à-vis the perceived level of security within gated communities, this study examined the impact of gated communities on residential property values to establish whether property values are higher within gated communities than their neighbourhoods and the impact of Onipetesi Estate on Idi-Mangoro and vice versa.

\section{Literature Review}

This section explored the various literatures on gated communities with a view to identifying the gaps to be filled by the current study, with particular reference to the impact of gated communities on property values.

According to Landman (2000b), there are various reasons for the emergence of gated communities and this has given birth to varied definitions, depending on the circumstances that led to the creation of each gated community; or the motive behind the desire to be enclosed in a private collective territory represented by the gated community. Majority of the gated community definitions and classifications are based on this kind of reasons. Studies about gated communities all over the world explain the main reason for their emergence as the increasing crime rate. Some residents decide to run away from this "risky" environment and live in a closed safely gated community, a typical example of such a scenario is South Africa. In Saudi Arabia, another type of gated community exists and the purpose is to provide the inhabitants with the same life style of their homelands so that they can freely practice their daily activities. These include, The Kingdom Compound in the country side of the capital Riyadh in Saudi Arabia which is reserved for expatriates.

In the literature, there is no single definition and no common consensus regarding the concept of 'gated communities'. Numerous terms are used to refer to this phenomenon. The terms used by researchers include: "gated communities" (Caldeira, 2000; Landman, 2000a), "gated enclaves" (McGoey, 2003), "enclosed neighbourhoods" (Landman, 2000a). The definitions and perceptions regarding what constitutes a gated community vary quite considerably; however, Blakely and Snyder, (1997), gave a general definition of gated communities as "physical privatised areas with restricted entrance where outsiders and insiders exist". The recent examples of gated communities are shaped by global socio-economic changes, marketing strategies of developers (Webster, 2002) and the spreading of architectural concepts and lifestyles by international migration. Gated communities remained rare until the advance of the retirement developments of the late 1960s and 1970s which were centrally planned. Blakely and Snyder (1997) have identified some 20,000 gated communities in the US accommodating over three million units (with seven to eight million residents), but McGoey, (2003) put the number of gated communities at more than twice that. 
Gated communities, scattered all around the world, differ from country to country, with respect to their characteristics and in particular with respect to different reasons for development viz. security, ethnicity and prestige (Gulumser and Levent, 2007). For instance, gated communities in the US are the indispensable type of housing for American cities, mainly for urban elites (Blakely and Snyder, 1997). In contrast, in Latin American countries, the phenomenon first emerged as summer resorts then become a solution for ethnicity (Coy and Pöhler, 2002). In Europe the primary reason for gated communities is the seasonal use of houses in coastal zones, on the other hand, in major cities like London and Amsterdam they have become a fashion trend. By contrast, in Asia and in Africa, these communities are solutions for daily problems of high crime rate and ethnic conflicts (Landman and Schöntiech, 2005). They dramatically restructure the urban patterns of many cities around the world. One of the greatest challenges for a better understanding of radical urban transformation is perhaps the parallel emerging phenomenon of gated communities that is fast moving from the US cities to the UK and to other European cities (Landman, 2000a). Gated communities represent the hope of security, appeal to consumers searching for a sense of community and identity, offer an important niche marketing strategy for developers in a competitive environment, keep out the unwelcome, generally associated with attractive amenities, and increase property values (Blakely and Snyder 1997; Grant, 2003).

On this basis, there are many types of gated communities with differing degrees of amenities, exclusivity and security. Researchers have developed their own typologies on the basis of the causes, consequences and significant implications of gated communities including issues like ethnicity, income, travel etc. (Blakely and Snyder, 1997; Landman, 2000a). Blakely and Snyder (1997) identified three main types of gated communities as lifestyle communities which focus on leisure activities with recreational facilities, common amenities, and shared services at their core. Lifestyle enclaves may include retirement villages, golf communities, or suburban new towns; Prestige communities serve as symbols of wealth and status for image-conscious residents where gates prevented the masses from seeing how the wealthy lived and lastly, security zone communities close off public streets to nonresidents. They reflect a fear of outsiders who disrupt neighbourhoods. Grant and Mittelsteadt (2004) identified eight (8) factors that differentiate gated communities from their neighbourhood to include functions of enclosure, security features and barriers, amenities and facilities included, type of residents, tenure, location, size and policy context.

\section{The Nature and Growth of Gated Communities}

Gated communities are also increasing in other countries, for example Spain, Portugal, Russia, Turkey, Egypt, Syria, Indonesia, Argentina, Brasilia and South Africa. In the suburbs of Greater Buenos Aires, gated communities are flourishing. In the 1990's it became a largescale form of permanent housing, accessible to the middle-class and today more than 300 of those fast-growing closed neighbourhoods host an estimated 20,000 residents (Landman, 2000a). In the same vein, Landman (2000b) opined that gated communities are also a rapidly growing phenomenon in South Africa and have especially taken off since the mid-nineties. One substructure of the Greater Johannesburg Metropolitan Council has recorded more than 360 road closures in their area.

In Nigeria today, the concept of gated communities is a fast growing one especially in response to safety and security all over the country. Equally one can found road/street closures in major cities of Nigeria. They came up in response to insecurity within the non-gated communities.

One of the consequences of government's inability to protect the life and property of all its citizens especially in developing countries is the formation of private alternatives to crime prevention and control. Gated communities, or enclosed neighbourhoods, are one such popular alternative (Landman and Schönteich, 2005). With the development of nation states, public police forces and air power, walled cities became redundant as fortresses to keep foreign invaders and marauding criminal gangs out. A relatively new trend as an architectural concept is that of the gated community. Gated communities are a generic term that includes enclosed neighbourhoods that have controlled access through gates or booms across existing roads, and security villages and complexes, including lifestyle communities which provide their enclosed residents with a range of non-residential amenities such as schools, offices, shops and golf courses. The development and growth of gated communities in Nigeria is more of a response to high level of insecurity in the nation's urban centres. It is not uncommon these days to see major streets close up with gates all in the bid for secure environment.

While the various literature reviewed above considered gated communities in terms of safety and security, homeland lifestyle (ethnicity), prestige, class distinction (social status) etc, this study focus on the impact of gated communities on residential property values, an area that is yet to be well studied. 


\section{Effects of Gated Communities on Urban Areas}

The rise of gated communities can lead to spatial fragmentation and separation in cities as a result of its security and financial implications. Gated communities give a sense of community, safety, security and social exclusion which lead to urban fragmentation and separation. A number of leading authors on gated communities highlight the potentials gated communities have to contribute to spatial fragmentation in urban areas. It is well known that in big cities, the current concern about security and maintenance of social order express themselves through social and spatial segregation processes. Examples of this phenomenon are the so called closed spaces -which can be residential, commercial or dedicated to the supply of services (Giglia, 2003). The fast spread of gated communities affects both the lives of the people who live in them and the urban sprawl. Gated communities do not only threaten, but also contribute to the city. They contribute to the city through the creation of new job opportunities, secured areas, better infrastructure and utilising inactive lands. The creation of new job opportunities and better infrastructure can be counted as contributions to the whole city at least for near vicinity, however, the secured areas is an advantage only for the inhabitants of gated communities.

Davis (1998) sees gated communities as manifestations of the "militarization of urban space" and, conclusively, of the class struggle for space. As such, while in the past the housing market forced the poor into the more or less closed ghettos in the cities, today the affluent segregate themselves within their own exclusionary and fortified enclaves. Where this exists sustainable urban growth is seriously endangered.

Considering the study area, the visible effects of Onipetesi Estate on Idi-Mangoro include the displacement of crimes to Idi-Mangoro and this made the residents felt increasingly vulnerable and subsequently adopted the $\mathrm{road} / \mathrm{street}$ closures as a means of safeguarding their lives and properties. Social and economic disparity was also noticeable as majority of the residents of Onipestesi Estate (gated community) are those high up the social and economic ladder who can afford the prevailing property values within the estate. On the contrary, majority of the residents of Idi-Mangoro are at the lower rung of social and economic ladder.

\section{The impact and implications of gated communities}

Landman, (2003) opine that while safety and security are not only the reasons, they constitute the main factors behind the proliferation of road closures and security villages. Consequently, the first question is always whether such responses reduce crime. There are mixed opinions about this, internationally and in South Africa. A national study by Blakely and Snyder in the USA found that some "security zones" (enclosed neighbourhoods) reported a reduction in crime after the streets have been closed. Others, however, report only temporary reductions, and some report no change at all (Blakely and Snyder 1997). In another study comparing four communities - two gated and two non-gated - Wilson-Doenges (2000) found no significant difference in the perception of safety between the gated and non-gated communities. In addition, she found that there was also no significant difference in the actual crime rates per capita between the gated and non-gated communities in both the high-income and low-income communities.

Landman (2000b) posited that in South Africa, almost all the security companies report a significant reduction in crime in enclosed neighbourhoods, while a number of large security estates experienced a few isolated cases of crime. The SAPS also generally agree that crime is reduced through physical target hardening on a neighbourhood scale. They do however acknowledge that it often displaces crime to surrounding neighbourhoods. One of the consequences is that these communities feel increasingly vulnerable and subsequently also apply for road closures or choose to move to a security estate/secure townhouse complex.

Others are however more skeptical about the effects on crime. According to Naudé (2003) gated communities do not always reduce crime. Rather very few crimes are reduced by the closure of existing suburbs and public roads. It can at most reduce some opportunistic or impulsive crimes such as theft, burglary and street crimes (for example pick-pocketing and snatch-and-grab crimes) which are mostly committed by opportunistic criminals who simply use the opportunity to commit crime while in the area. In addition, a large number of occasional visitors must still be allowed into the area, for example family and friends of homeowners, gardeners and domestic workers, municipal workers, building and construction workers, Telkom staff, repair and garden services, delivery services and people looking for work with the result that there is still a high crime risk in the area. Naudé (2003) warns that crime statistics collected by members of the public in support of the closure of the suburb are often not reliable and can even be misleading. What seems to be undisputable, however, is that living in a security village or enclosed neighbourhood reduces the fear of crime inside the protected area. 


\section{Urban Sustainability and Gated Communities}

The UN Habitat's Programme for Sustainable Cities define "a sustainable city is a city where achievements in social, economic and physical development are made to last. It strives for:

Economic efficiency in the use of development resources (including goods and services provided by the natural environment)

Social equity in the distribution of development benefits and costs (with special emphasis on the needs of low income groups)

Avoidance of unnecessary foreclosure of future development options."

This description incorporates the three pillars of sustainable development, namely economical, social and environmental, to describe the (ideal/envisaged) performance of a city, i.e. how the city should function, what it should provide for its citizens and what the relationship should be with the natural environment

On the other hand, the United Nations Development Programme promoted the notion of Sustainable Human Development as development that centres on people's choices and capabilities, that generates economic growth while distributing its benefits equitably, and that generates the environment rather than destroys it. In addition, it promotes development that empowers men and women rather than marginalising them. Hall and Pfeiffer (2000) extended this notion to the idea of "multiple sustainability" (i.e. the multiple dimensions of sustainability). Applying this to the city, they came up with a number of key dimensions or aspects of sustainability. These are:

A Sustainable Urban Economy: Work and Wealth

A Sustainable Urban Society: Social Coherence and Social Solidarity

Sustainable Urban Shelter: Decent Affordable Housing for All

A Sustainable Urban Environment: Stable Ecosystems

Sustainable Urban Access: Resource-Conserving Mobility

Sustainable Urban Life: Building the Liveable City

Sustainable Urban Democracy: Empowering the Citizenry

The sustainability contribution of gated communities to urban area needs to be examined along the social and environmental perspectives on a long term basis rather than the short term economic basis. Social relations and social interactions within public spaces are fundamentally determined by the needs, attitudes and perceptions of the people who live there. In this respect, the locality and nature of housing is a major determinant of how connections between individuals and communities are formed and maintained. It is generally accepted that the distribution of residential units and their occupants is not a random event but the product of complex social, economic and political processes. One of the most significant results of these processes is that housing consumption patterns can result in segregated areas otherwise known as enclaves or ghettos. Looking at the long term impact of gated communities on urban development, Landman (2000a) identify the key issues relating to gated communities as: a sense of community, safety and security, social exclusion, urban fragmentation and separation, urban planning and management and financial implications.

\section{Research Methods}

The primary data used for this study was obtained through the use questionnaire and personal interviews. While questionnaire was administered on the 230 residents of Onipetesi Estate, 40 copies were administered on the Estate Surveying and Valuation firms managing properties within Onipetesi Estate and Idi-Mangoro neighbourhood. This was supplemented by personal interview with respondent Managing Agent for clarification on data obtained from the respondents. While questionnaire was administered on all the 230 residents of Onipetesi Estate, the 40 Estate Surveying and Valuation firms are among the 62 firms in Ikeja as contained in the Nigerian Institution of Estate Surveyors and Valuers, 2009 Directory. The questionnaires were administered on the head of each of the Estate Surveying and Valuation firms. A total of 134 (58.26\%) and 25 (62.5\%) copies of the questionnaires were retrieved from the residents and Managing Agents respectively. In analysis of the data collected for this study, the use of descriptive statistics such as frequency tables and percentages was employed. Secondary data used was obtained from earlier publications like journals, textbooks, to mention just a few.

\section{Result and Discussion}

This section contains the results of the data analysis so as to be able to come up with useful deductions and these are as shown in tables 1 to 6 . Table 1 shows the period of residency of the respondents within Onipetesi Estate. It can be seen that about $71 \%$ of the respondents have lived for more than 5 years in the estate. It could therefore be deduced that most of the respondents have lived long enough in the estate to have a reasonable opinion on the effects of the estate enclosure on the residential property values. Table 2 shows that approximately $86 \%$ of the respondents agreed that the security provided within the estate enhances the value of the properties in the estate. 
This could be due to high influx of home seekers within the estate. A comparative analysis of rental trend between Onipetesi Estate and Idi-Mangoro (an adjoining neighbourhood to the estate) was carried out and Table 3 reveals that over the period of 2005 and 2009 the rental values of residential properties in Onipetesi Estate are consistently higher than that of Idi-Mangoro. The rent in Onipetesi Estate is relatively higher than those in Idi-Mangoro by about $17 \%-25 \%$ for the different residential units. This shows that residential properties in Idi-Mangoro - a non-gated community, command a relatively lower rental value than residential properties in Onipetesi Estate. Figure 1 is a graphical demonstration of the trends in rental values over the same period of time. The study determined to establish the effect of security facilities on the demand for properties within Onipetesi Estate, the result as contained in Table 4 shows that $76 \%$ of the respondents agreed that the estate's system of gates and other security systems led to increase demand for residential properties within the estate. This position, in no doubt, could be due to individual's quest for secured haven both for their lives and properties. As a follow-up to Table 4, the study also set to establish whether the existence of security facilities forms the basis for rent negotiation within the estate. Table 5 reveals that about $69 \%$ of the respondents posit that security facilities provided by the community serve as important consideration in negotiation during a property transaction. It could therefore be concluded that security facilities available is a strong factor affecting client's decision on residential properties within the estate. To further probe into the importance attached to gated community, respondents were requested to indicate the type of community they would prefer to live in and the response is as shown in Table 6 . The table shows that about $84 \%$ of the respondents prefer to live in gated communities. This may be as a result of protecting their lives and properties from marauders.

\section{Conclusion and Recommendations}

Gating of Onipetesi Estate came as a response to high rate of criminal activities in Lagos State generally and the estate in particular, most especially due to armed robbery. The study also established that the estate system of gates and security, in the opinion of the respondents, resulted in high demand for residential properties within the estate which in turn, result in higher rentals than the immediate neighbourhood (Idi-Mangoro) of the estate. In other words, the study established that residential properties are more expensive within gated communities than non-gated communities. In terms of economic sustainability, gated communities provide good basis for improving the standard and quality of valuation of residential properties, however both environmental and social sustainability should be given equal recognition, especially with the various criticisms leveled against gated communities in terms of their sustainability contribution to urban growth. The sustainability impact of gated communities on urban development should be measured in terms of sustainable urban economy, urban society, urban life and urban democracy.

\section{References}

Atkinson, R. and Flint, J. (2004). Fortress UK? Gated Communities, The Spatial Revolt of the Elites and Time-space Trajectories of Segregation. Housing Studies Vol. 19, No.6, 875 - 892.

Blakely, E.J., and Snyder, M.G. (1997). Separate Places: Crime and Security in Gated Communities. in: Felson, M. and Peiser, R.B. (eds.), Reducing Crime through Real Estate Development and Management, pp. 53-70. Washington, D.C.: Urban Land Institute.

Caldeira, T. P. R. (2000). City of Walls: Crime, Segregation and Citizenship in Sao Paulo. University of California Press, Berkeley. CA.

Coy M., and Pohler M. (2002). Gated communities in Latin American megacities. [Online]: Available: www.crisisstates.com/download/seminars/Lemanski.12Nov08.pdf

Dillon, D. (1994). Fortress America: More and More of us Living behind Locked Gates. Planning, Vol. 60, pp 2 8 .

Giglia A. (2003). Gated communities: building social division or safer communities. Location; [Online]: Available: www.gatedcommunities.de/effects

Grant J. (2003). Planning Responses To Gated Communities in Canada. Paper Presented at Gated Communities: Building Social Division or Safer Communities? Glasgow, September 18-19, 2003.

Grant, J. and Mittelsteadt L. (2004). Types of Gated Communities Environment and Planning B: Planning and Design 2004, Vol. 31, pp 913 - 930.

Gulumser A. A. and Levent B. T. (2007). Through the Sky: Vertical Istanbul Gated Communities. Location; [Online]: Available: www.bidoun.com/bdn/.../istanbuls-gated-communities 
Hall,P. and U. Pfeiffer 2000 Urban Future 21: A global agenda for twenty-first century cities. London, E \& FN Spon. p. 17.

Landman K. (2000a). Gated Communities and Urban Sustainability Location: Taking a Closer Look at the Future: $2^{\text {nd }}$ Southern African Conference on Sustainable Development in the Built Environment Strategies for a Sustainable Built Environment 23 - 25 August 2000 Pretoria, South Africa [Online]: Available: www.csir.co.za/gated_community/landman.

Landman, K (2000b) An international review of gated communities. CSIR Publication, Pretoria

Landman, K. (2003). Gated communities in South Africa: a national survey. Pretoria: CSIR Publication.

Landman K., and Schönteich M. (2005). Urban Fortresses Gated Communities as a Reaction to Crime. [Online]: Available: http://www.feem.it/Feem/Pub/Publications/EURODIVPapers/default.htm

Low, S. (2003). Behind the Gates: Life Security and the Pursuit of Happiness in Fortress America. London, Routledge.

McGoey, C. E. (2003). Gated Community: Access Control Issues, Crime Doctor. [Online]: Available: www.informaworld.com/index/gu0dvqbbfuj65g27.pdf

Naudé, B. (2003). The Effectiveness of Public Road Closures in Suburban Areas as a Crime Reduction Measure. Security focus: Vol. 21, No. 6, pp $34-36$.

Ratcliff. J. (1978). An introduction to urban land administration, (1st ed.). London: The Estate Gazette Ltd.

Webster, C. (2002). Challenging The Public Realm: Gated Communities In History. suburbs.planning.dal.ca/Docs/gates\%20in\%20history\%2008.pdf

Wilson-Doenges, G. (2000). An Exploration of Sense of Community and Fear of Crime in Gated Communities, Environment and Behavior, Vol. 32 No. 5, September 2000 597-611, Sage Publications, Inc.

Table 1. Duration of Residency in Onipetesi Estate

\begin{tabular}{|c|c|c|}
\hline $\begin{array}{l}\text { Duration } \\
\text { (Years) }\end{array}$ & Frequency & Percentage \\
\hline 2 & 11 & 8.2 \\
\hline 3 & 7 & 5.2 \\
\hline 4 & 21 & 15.7 \\
\hline $5+$ & 95 & 70.9 \\
\hline Total & $\mathbf{1 3 4}$ & $\mathbf{1 0 0 . 0}$ \\
\hline
\end{tabular}

Table 2 . Does the security provided by the community affect property value?

\begin{tabular}{|l|c|c|}
\hline Opinion & Frequency & Percentage \\
\hline Strongly Agree & 24 & 17.9 \\
\hline Agree & 91 & 67.9 \\
\hline Disagree & 19 & 14.2 \\
\hline Total & $\mathbf{1 3 4}$ & $\mathbf{1 0 0 . 0}$ \\
\hline
\end{tabular}

Table 3. Trend in rental value of residential properties in Onipetesi Estate and Idi-Mangoro Neighbourhood

\begin{tabular}{|l|l|r|r|r|r|r|}
\hline \multirow{4}{*}{$\begin{array}{l}\text { Onipetesi } \\
\text { Estate }\end{array}$} & Type of property & $\mathbf{2 0 0 5 ( \mathbf { N } )}$ & $\mathbf{2 0 0 6}(\mathbf{N})$ & $\mathbf{2 0 0 7}(\mathbf{N})$ & $\mathbf{2 0 0 8}(\mathbf{N})$ & $\mathbf{2 0 0 9}(\mathbf{N})$ \\
\cline { 2 - 7 } & 5 bedroom duplex & 300000 & 350000 & 380000 & 400000 & 450000 \\
\cline { 2 - 7 } & 3 bedroom flat & 170000 & 220000 & 250000 & 280000 & 320000 \\
\cline { 2 - 7 } & 2 bedroom flat & 120000 & 160000 & 200000 & 250000 & 280000 \\
\hline \multirow{3}{*}{ Idi -Mangoro } & 5 bedroom duplex & 250000 & 250000 & 280000 & 300000 & 350000 \\
\cline { 2 - 7 } & 3 bedroom flat & 100000 & 120000 & 160000 & 200000 & 250000 \\
\cline { 2 - 7 } & 2 bedroom flat & 60000 & 80000 & 100000 & 150000 & 200000 \\
\hline
\end{tabular}


Table 4. Security facilities provided by the estate effects on property demand

\begin{tabular}{|c|c|c|}
\hline Opinion & Frequency & Percentage \\
\hline Increased Demand & 102 & 76.1 \\
\hline Decreased Demand & 11 & 8.2 \\
\hline Not Sure & 21 & 15.7 \\
\hline Total & $\mathbf{1 3 4}$ & $\mathbf{1 0 0 . 0}$ \\
\hline
\end{tabular}

Table 5. Security facilities available as a basis for negotiation

\begin{tabular}{|l|c|c|}
\hline Opinion & Frequency & Percentage \\
\hline Yes & 92 & 68.7 \\
\hline No & 42 & 31.3 \\
\hline Total & $\mathbf{1 3 4}$ & $\mathbf{1 0 0 . 0}$ \\
\hline
\end{tabular}

Table 6 . What kind of community would you prefer to live in?

\begin{tabular}{|l|c|c|}
\hline Opinion & Frequency & Percentage \\
\hline Gated Community & 112 & 83.6 \\
\hline Non- Gated Community & 14 & 10.5 \\
\hline Not Sure & 8 & 5.9 \\
\hline Total & $\mathbf{1 3 4}$ & $\mathbf{1 0 0 . 0}$ \\
\hline
\end{tabular}

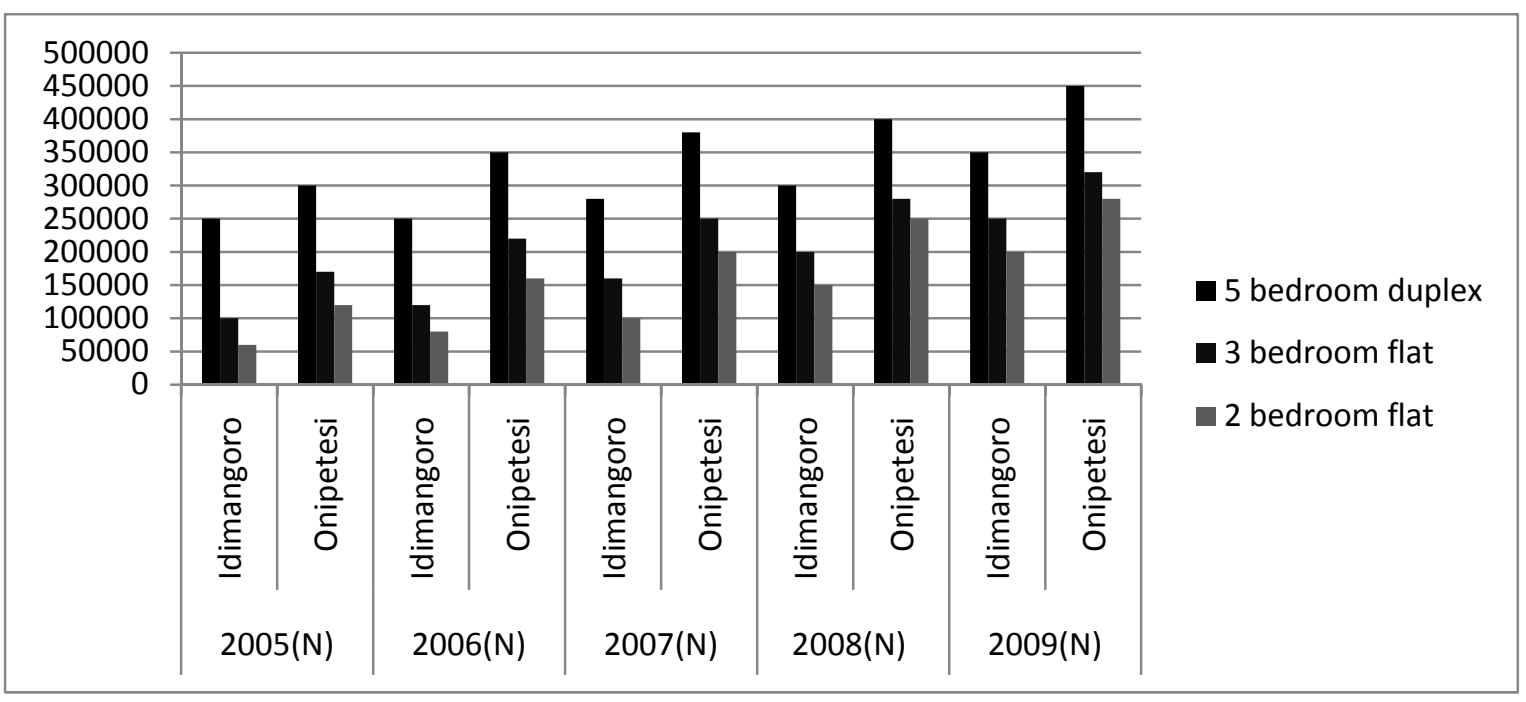

Figure 1. Graphical presentation of the trend in rental value of residential properties in Onipetesi Estate and Idi-Mangoro Neighbourhood 